\title{
Analysis of the Myths, Photographs and Laws in China Men
}

\author{
Minglan Zhang \\ Foreign Language Department, Huaiyin Institute of Technology, 223003, Jiangsu, China \\ Fade Wang \\ Foreign Language Department, Huaiyin Institute of Technology, 223003, Jiangsu, China
}

\begin{abstract}
The presentation of myths, photographs and laws in China Men, thematically related to Chinese American immigration stories, is an important strategy to reconstruct Chinese American history. By citing photographs and presenting law, Kingston reclaims her male ancestors' past and subverts the monologue of American official history. By rewriting myths, Kingston exposes the dilemma of Chinese Americans and deconstructs a series of American myths such as the myth of America as a melting pot, the myth of Gold Mountain, the myth of freedom and democracy; these myths provide a way for Kingston to write Chinese Americans into American history.
\end{abstract}

Index Terms-China Men, rewriting myths, citing photographs, presenting law, deconstruct western grand narrative, reconstruct Chinese American mythic history

\section{INTRODUCTION}

Maxine Hong Kingston is one of the most successful Chinese American writers. Up to now, Kingston has published four works of fiction and non-fiction, namely, The Woman Warrior (1976), China Men (1980), and Tripmaster Monkey: His Fake Book (1989), The Fifth Book of Peace (2003), plus a collection of prose, Hawaii One Summer (1978) . The Woman Warrior tells of a second -generation girl's groping for a viable female identity as a Chinese American in the late 1960s. The book was a great success, and in 1976 won the National Book Critics Circle Award for the best nonfiction. China Men, a companion piece to The Woman Warrior, has males in Kingston's family as the chief characters. While her first book honors the women of Kingston's family, China Men celebrates the lives and accomplishments of the males in her family. Again her literary talents were lauded. On its release, the book was immediately named to the American Library Association's Notable Books List, and won the National Book Award for nonfiction.

China Men is composed of six distinct but related principal stories about the men in Kingston's family. "The Father from China" is the story about Kingston's BaBa (father), in which Kingston tries to imagine the essential events of her father's life in China from his auspicious birth and through his education, to his emigration to the Gold Mountain. "The Great Grandfather of the Sandalwood Mountain" is about the adventures of Bak Gong (great grandfather) on the Hawaiian sugar cane plantation as a contract worker. "The Grandfather of the Sierra Nevada Mountain" tells of the heroic story of Ah Gong (grandfather) during the construction of the First Transcontinental Railroad. "The Making of More Americans" deals with identity problem facing Chinese Americans. Father returns in "The American Father" as a new American with a house and business after years of struggle. The book ends with "The Brother in Vietnam". This is a section devoted to the American-born generations who joined the American army and won the solid position for their family in America.

One typical structural feature of China Men is the juxtaposition of stories with vignettes. Each principal story about the males in Kingston's family is framed with one or two vignettes, which cover short tales, myths, fragments of law, and news reports. These vignettes, varying in length, origin, and theme, are ingeniously arranged. However, their function was once ignored or misinterpreted by some critics who criticized that these myths were so arbitrarily adapted that they totally lost their true features and made readers confused and annoyed, or that they were loose episodes, having no thematic cohesiveness with the historical narratives. But recently, the myths and historical facts in the book have aroused increasing interest of many critics. Robert G. Lee points out that "for Kingston, myths necessarily rebuilt, have a strategic value in helping to analyze contemporary events. She recognizes that the power of myth resides in its capacity to be recontextualized and inscribed with new meanings" (Lee, 1991, p. 59). Yuan Yuan states that myths in China Men "function as a semiotic empowerment in the process of identity formation" (Yuan, 1999, p. 292). Gao Yan, by approaching the myths from the perspective of the biographical stories of the Hong family, rearranges them into four themes in relation to the main stories, namely, racial oppression, claiming the land, breaking silence, and cultural displacement ( Gao,1996,p.53-95).

The author of this thesis agrees with these critics' viewpoints, and from the perspective of history-writing, to the author's mind, the myths, laws and photographs which run parallel to the family stories thematically reinforce and 
complement the stories, are indispensible parts of creating Chinese American history. Based on the previous studies, the author of this thesis tries to analyze the myths, laws and photographs in China Men, and reveals how Kingston reconstructs Chinese American history through re-reading facts and rewriting myths.

\section{RE-READING FACTS}

\section{A. Presenting Laws}

Besides retelling the heroic stories of her male ancestors through her memory and imagination, Kingston throughout China Men furnishes many factual materials which include laws, photographs and newspaper reports. These factual materials, combined with the family stories, pose a challenge to the authenticity and authority of mainstream American history.

After recounting grandfather Ah Goong's stories, and right in the middle of the book, Kingston with little comment inserts a chapter titled "The Laws", which takes the form of a chronicle and enumerates the various U. S. regulations and laws discriminating against Chinese Americans from the Burlingame Treaty of 1868 to the immigration law of 1978. Being baldly substantial documentary material, this chapter is criticized by some to be anomalous with the variegated narrative in the rest of the book. However, it is recognized and praised by such critics as King-Kok Cheung, Donald Goellnicht, and Shan Dexin. The author of this thesis agrees with those critics who think that this chapter serves well the form and content of the book. Firstly, this chapter is inserted by the author to instruct American people who are ignorant of the Chinese American history and content to read her texts from the vantage point of Orientalism. As Kingston states:

The mainstream culture doesn't know the history of Chinese Americans, which has been written well. The ignorance makes a tension for me, and in the new book [China Men] I just couldn't take it anymore. So all of a sudden, right in the middle of the stories, plunk - there is an eight-page section of pure history. It starts with the Gold Rush and goes right through the various exclusion acts, year by year. (Kim, 1982, p. XVII)

Secondly, this chapter provides the general American reading public with a brief chronicle of oppression against which the heroic deeds of the idealized fathers can be judged. Quite different from immigration histories of other minorities, early Chinese American history was inseparable from American laws. Discriminatory laws had accompanied the whole immigration process of Chinese Americans and manifested as its distinctive features. Therefore, Kingston's recounting these laws is of special significance to deal with Chinese American history. By presenting her ancestors' stories against American discriminatory laws, Kingston not only exposes the harsh political environments under which Chinese Americans were forced to labor for more than a century, but makes her historical stories more resonant and real. As Cheung points out, "Kingston's sketches of China Men in the Hawaiian fields and on the railroads may not be 'factual', but they are surely truer than the reductive images inscribed in the merciless canons" (Cheung, 1993, p.118).

Thirdly, this chapter embodies the climax of racism and the domineering voices that Kingston's talk-story seeks to confound. As Foucault notes in Power/Knowledge, "Law [is] the principal mode of representation of power" (Foucault, 1980, p. 141), and the widespread national racism against the Chinese will inevitably lead to and ultimately be enforced by laws. Thus Kingston's representation of the laws is a straightforward, and forceful way of exposing the America's discrimination against Chinese Americans.

Finally, the style of the chapter and its location in the book helps reinforce the theme of the book. As Goellnicht states, "The Laws" is ironic in three senses. First, the irony surfaces from the facts themselves, as in the justaposition: "The United States and the Emperor of China cordially recognize the inherent and inalienable right of man to change his home and allegiance .... [but] 1868, the year of the Burlingame Treaty, was the year 40,000 Chinese ancestry were Driven Out" (p.152). "Though the Chinese were filling and leveeing the San Joaquin Delta for thirteen cents a square yard, building the richest agricultural land in the world, they were prohibited from owning land or real estate"(p.153). Secondly, the narrative of this chapter carries an ironic undertone by "imitating the monological voice of authorizing history" and by "uncover[ing] both the dullness of this voice and its deafness to other, competing voices, those of the minorities suffering legalized discrimination"(Goellnicht,1992,p.196). Thirdly, there is irony in the position of this chapter. "It occupies the middle of the book, a centric position that would appear to be one of (legalized) authority, yet this centric authority of American laws is subverted and contested by 'eccentric' or marginal, but richly imaginative stories of China Men that surrounds it" (p.197). Goellnicht illustrates that the stories of China Men, surrounding this chapter, do not strengthen the monological and monotonous authoritative discourse, but subvert it.

Thus the above analysis shows that, in both style and content, the law in this chapter furnishes an essential strategy to rewrite Chinese American history.

\section{B. Citing Photographs}

In addition to presenting the laws, Kingston also resorts to photographs as a strategy to reclaim her male ancestors' past and to challenge the status of official history.

Traditionally, the photograph has been seen in western culture as a representation of nature, an unmediated transcription of reality into film. Just as Trinh T. Minh stated, "The tyranny of the camera goes unchallenged" (Zackodnik, 1997, p. 55). This notion of photography as veracity endows the photos with the capacity to prove, to either present factual evidence or stand as a fact itself. Because of the supposed truth value, the photograph is often used to 
bestow authenticity upon prevailing ideologies to prove the monolithic narrative of conventional history. However, the capacity of photograph as a piece of factual evidence is interpretive because "what the photograph communicates arises only from the meaning we ascribe to it. Meaning does not inhere in the photograph itself" (p.55). That means that, rather than presenting an evidential and singular truth, the silence of a photograph invites a plurality of meanings and speculations, depending on how or who interpret it. That is what Susan Sontag described as a "polylogue" (p.56). Perhaps it is this dualistic aspects of the photograph that has attracted Kingston to employ photograph as a narrative in China Men.

As a complement to the historical stories coming from the author's memory, some photographs in China Men prove the truth of these stories and the factual existence of these (fore) fathers as Americans. When Kingston's father was working as a laundryman in New York, he sent many pictures back to his wife from time to time. In a spring picture, father and his partners wore expensive clothes, laughing and standing next to a Keep Off the Grass sign. In a winter picture, he sat on a rock in Central Park in his grey coat and jaunty hat and leather gloves lined with rabbit fur (p.67). Father also had several snapshots taken when he was standing by motorcycle, or in a ferryboat on their weekend outings.

Though these photographs are taken, to some extent, to flaunt father's material success in America, and can not be regarded as a true reflection of his American life, one thing is certain: they do confirm that father has appropriated America as part of his reality, and his existence in America, his sweating in the laundry is a truth that cannot be denied.

Besides father, other sojourner forefathers never forgot to envelop "a yearly picture taken at the photo studio," (p.106) when sending their wages home. These yearly photographs document both the passage of time and their presence in Hawaii or Sierra Nevada Mountain.

While employing photographs to present her family history, Kingston exposes the American authority's abuse of photographs to cover Chinese American history. The railroad photograph is one good example. When the railroad was completed, China Men did cheer with the white. They acted like mad men, throwing their hats in the air, jumping up and down, and screaming Yippee like cowboys. Yet, when the white demons posed for photographs to commemorate the Greatest Feat in the history of mankind, "The China Men dispersed. It was dangerous to stay. The Driving Out had begun. Ah Goong does not appear in railroad photographs" (p.145). Instead of recording fact, the historical message given in this photograph is misleading. It shows that the whites were the sole builders of the railroad, whereas its true makers, the Chinese workers, were expelled from the camera's gaze. Similar idea finds expression in the photograph of Bak Goong and his New Year dragon. To celebrate his New Year in Hawaii, Bak Goong built the best and highly praised New Year dragon in his life and had his picture taken inside the dragon. However, splendid as the dragon could be, Bak Goong, the maker of the dragon, was disappropriately minimized and became unrecognizable in the picture. This scene vividly reveals that Chinese Americans who, like Bak Goong, had devoted the best part of their lives to the building of the most splendid and greatly admired railroad dragon in America, are purposefully excluded from the mainstream American history. The official abuse of photo is an echo of Foucault's notion that photograph, as a body of knowledge about history, is the result of the interplay of various forces or discourses.

JanMohamed, a post-colonial critic, commented that, "archival work, as a form of counter-memory is essential to the critical articulation of minority discourse" (Jan- Mohamed,1990,p.6). Thus Kingston's presentation of the laws and the photographs concerning Chinese Americans is of special significance in subverting the monologue of American official history and in reconstructing Chinese American history.

\section{REWRITING MYTHS}

The preceding part demonstrates Kingston's strategies of reconstructing Chinese American history through re-reading facts. In this sense, the act of re-reading is an act of righting as well as empowering. In this part, my focus is on another strategy - rewriting myths. Rewriting myths which runs parallel to the historical narrative function to expose the dilemma of Chinese Americans as well as re/deconstruct myths.

\section{A. Exposing the Dilemma of Chinese Americans}

On several occasions Kingston points out that William Carlos Williams' In the American Grain (1925) is a great inspiration for her to treat Chinese American history mythically. In the American Grain is a series of meditations on American history and explorations of myths that shape the history. In this book, Williams takes a daring step of identifying the Icelandic sagas as integral components of the American literary tradition, as well as the early texts in American history. By expanding the American narrative, Williams creates a space for the inclusion of the submerged groups whose stories have been excluded from Anglo-centric histories of America. Greatly influenced by Williams' daring act, Kingston states, "I wanted to do American history in that same way, especially for China Men, and I was so lucky because he ended at the Civil War and I pick up at the Civil War when the Chinese Americans came, and I showed how the Chinese made the bands of steel, which is a railroad, and they banded the country back together again. This is the way I want to think about American history, about history, in that mythic, true way" (Bonetti, 1998, p.39). With China Men as the continuation of Williams' mythic narrative, Kingston does add her version of America's origin, which overlaps the arrival of the first Chinese immigrants with the Civil War (In the American Grain ends in 1860 with the Civil War), therefore incorporating the stories of her immigrant ancestor's courage, suffering, and hard work into the 
grand narrative of America.

The book begins with "On Discovery", a myth taken from the Chinese novel, Flowers in the Mirror by Li Ruzhen (1763-1830) of the Qing Dynasty. In this opening episode, the protagonist, Tang Ao, crossed the ocean and came upon the Land of Women, when he was looking for the Gold Mountain. There, Tang Ao was captured and forced to endure all the tortures that were usually done to ancient Chinese women by men: two women sat on him while another pierced his earlobes, and threatened to sew his lips to silence him when he cried for pain. They bound his feet, plunked his facial hair, painted his lips and cheeks, and fed him on some food that could shine his hairs and improve his womb. What's more, after transformed into an Oriental courtesan, Tang Ao was summoned to serve the empress of the land (p.2). The myth concludes as fellows: "Some scholars say that the country [the Land of Women] was discovered during the reign of Empress Wu (A. D.694-705), and some say earlier than that A.D. 441, and it was in North America” (p.2).

Since Kingston associates the Land of Women with North America, critics familiar with Chinese American history will readily see that the ignominy suffered by Tang Ao in a foreign land symbolizes the multiple castration of China Men by the dominant American culture. Just as Tang Ao was deprived of his masculinity, metaphorically feminized, Chinese Americans were sexually castrated in the New World. Deprived of the right to marry white women or reunite with their wives, these early sojourners, confined in the bachelor society of various Chinatowns, were obsessed with sexual stress and lovesickness. As feminized Tang Ao was forced to wash his foot-binding bandages which looks like women's underwear, and serve meals at the queen' s court, emasculation of China Men also comes in the form of menial occupation and enforced invisibility. The contributions of the early Chinese immigrants who built railroads, mined gold, and cultivated plantation, long went unrecognized. Furthermore, because white workers could not brook Chinese competitors, after the completion of the railroad, these Chinese laborers were compelled to work as house servants, restaurant waiters, or laundrymen. Edged into such demeaning jobs traditionally done by women in old China, China Men were ridiculed or exploited for their involuntary occupational "feminity". Besides sexual and occupational emasculation, Chinese Americans were linguistically castrated. As Tang Ao was forced into silence, the Chinese in America were in a state of being silenced. To survive the adversity, they had to endure the imposed silence, as in BaBa's case, or externally imposed silence by the whip of white overseers, as in the case of Bak Goong. This deprivation of language was virtually an affront to their manhood as well as their cultural identity. In a word, Tang Ao's traumatic experience intimates the embarrassed situation of Chinese Americans in the latter half the $19^{\text {th }}$ century and the first half of the $20^{\text {th }}$ century at the mythic level.

The theme of silence and silence-breaking is still mythically treated in two vignettes, "On Mortality" and "On Mortality Again", which are juxtaposed with stories of Bak Goong and Ah Goong. In the former myth, a man named Tu Tzu-Chun is offered immortality by a Taoist monk if he can pass the test of remaining silent when he faces with various illusions. Tu succeeds in refraining from speech until the last test when he is reincarnated as a mute woman and watches her husband dash her baby against the wall to provoke her silence. In spite of Tu's ability to endure sorrow, fear, joy, and torture, his failure to overcome love leads to mortality of the human race. Similar story recurs in "On Mortality Again". Maui, the Trickster in Polynesian mythology seeks to steal Hina's heart that will bestow immortality on human beings. Before he enters the body of Hina, he instructs animals around to keep silent. However, when he almost succeeds in taking the heart out, a bird catches sight of his legs wiggling out of her vagina and bursts into laughter. The laughter wakes Hina who kills Maui by shutting herself.

The two myths convey two seemingly paradoxical themes: to break silence leads to death or to keep silent is the most painful experience for human beings. Considering Kingston's insistence on the necessity of silence-breaking, a reader may easily recognize that Kingston means the latter. What she wants to express here is that the rule of silence is so cruel that to follow it means to choose death. Therefore, to break silence and claim one's voice is of vital importance for people to live soundly. This theme echoes the stories of Bak Goong and Ah Goong who strive to break the rule of silence not only themselves $\mathrm{f}$ but also for all the Chinese workers, not only in literal sense but also in metaphorical way. In a word, by equating silence with death, Kingston exposes the inhumanity of hegemonic discourse which suppresses the voices of Chinese Americans, and reiterates the necessity of breaking silence at the mythical level.

Kingston also explores the immigrants' embarrassed identity in "The Li Sao: An Elegy". Taken from Qu Yuan's story in classical Chinese literature, this myth reflects the immigrants' embarrassed situation between two cultures that deny them: their poignant efforts to search for home and identity, and their helpless and sensitive inner world. QuYuan was a poet and loyal minister in the Warring States of ancient China. He advised the King of Chu not to wage a war against the Kingdom of Qin, but the king listened to the slander from the warmongers. As a result, Qu Yuan lost the favor of the king and was banished to the border area of the Center. After roaming in the remote area for twenty years, he finally became disillusioned, and drowned himself in the Miluo River (in Hunan Province).

Kingston vividly represents Qu Yuan's emotional dilemma when he would neither return to his home nor stay in any place he traveled to. "He sang poems wherever he went, haggard and poor, always homesick, roving from place to place... No home anywhere. He saw the entire world, but not his homeland...The distance between him and home grew farther each day" (p.257). So he complained, "My old wife has gone to a stranger district, wind and snow separate us... Birds fly back to last year's nest; foxes face the hill to die, but I cannot go home...Time runs like water and takes my youth... I am the phoenix dispossessed.”(p.257-258) Qu Yuan expressed his perplexity in a long poem and presented it to the soothsayers, but got no answer. Instead, he was questioned by the Witch of Future, "Why do you 
want just one country?" Realizing that "he was an orphan who traveled everywhere because one place was denied him", and "escape and return were equally impossible"(p.258), Qu Yuan killed himself.

This myth mirrors the awkward situation of many Chinese Americans like BaBa. Emigrating at their early ages, and cherishing a hope of assimilating into the "melting pot", these Chinese immigrants adopted American way of life, and were not willing to go back. However, as a colored people, the process of assimilation into white society was far more complex and difficult than that of Qu Yuan, because their adopted country never considered them as equal. Instead, it tried to suffocate or marginalize them in every possible ways. Edged into such a predicament, Chinese immigrants, like $\mathrm{Qu}$ Yuan, became orphans spiritually. In this sense, "The Li Sao: An Elegy", which explores the predicament and problematic identity of the exile, is a song of diaspora of the Chinese Americans.

Therefore, corresponding to but transcending the historical level, these myths create a universal note of alienation for Chinese Americans.

\section{B. Re/Deconstructing Myths}

Running parallel to dealing with the dilemma of Chinese Americans, the myth in China Men has another functiondeconstructing American myths and reconstructing Chinese American myths.

Compared with other nations which have long history and ancient mythology, America as a new nation has no mythology in the strict sense. However, since its foundation, America has been fabricating various myths of her own. For instance, the myth of democracy and equality, the myth of the melting pot, the myth of self-made Alger, the Gold Mountain myth, the Western Frontier myth and the like. Over the past two centuries, due to the dissemination of various mass media, these myths have been rooted in the minds of American people, and become part of the American culture.

Myths do play an important role in the cultural life of America. Particularly during the early period, the development and construction of the New World was indebted to these myths which encouraged and attracted thousands of pioneering souls over the world. However, American myths are not always inspiring and enlightening. There are some myths which turn out to be deceptive, misleading, or even dangerous. Attracted by these negative myths, many non-white immigrants have found that the harsh reality is quite different from these dazzling myths, because one of the durable myths of the American society - the myth of white's superiority over the colored ones-justifies the various laws to exploit and discriminate the non-white. Compared with large numbers of heroic myths about the white in American culture, Chinese American, despite their great contributions, is a minority group without myths, heroes and history. Enraged by the act of erasing Chinese Americans from American myth, Kingston, taking up her pen as a weapon, strenuously retorts these negative myths and attempts to carve a place for her ancestors in the American mytho-history. By assigning ideological meaning to the history of early Chinese Americans, Kingston makes the American fathers mythic figures and incarnation of heroic ideals and qualities. By demystifying the American myth, especially the myth of Gold Mountain for immigrants, Kingston attempts to empower Chinese Americans and make them the pioneers of America.

"On Discovery" is a metaphor of Chinese Americans' subjugated experience in America. However, to read this myth as just a reflection of their embarrassed situation alone is to obscure its significance. Kingston's real intention is to re/deconstruct a series of myths.

Firstly, by situating the adventure in North America and specifically designating the date when Tang Ao arrived in North America, Kingston deconstructs the myth that the land was discovered by the white, and suggests that the land could have been discovered by a brave Chinese more than five centuries before the Icelandic voyagers conjured by Williams.

Secondly, this myth challenges the authenticity of the Gold Mountain myth. Before Tang Ao was captured, he never sensed the imminent danger of being transformed into a woman for he was "not on guard against ladies"(p.3). Instead, he was charmed with the beautiful land and ladies. Like Tang Ao who was seduced by the Gold Mountain myth, large numbers of Chinese traveled across the ocean in the hope of scooping up free gold, having no presentiment of the danger before finding themselves caught in a stifling situation.

The seductiveness of the Gold Mountain myth is reinforced again in "The Ghostmate", a Chinese fable in which a young man pampered by a gorgeous widow eventually discovers this lover a succubus. The Gold Mountain myth is embodied in this myth in many aspects. The beautiful lady dressed in the old style indicates the deceptive charm of American dream. Her beautiful house with abundant riches symbolizes the fantasy of America as a country with piles of gold for immigrants. Her promises to the young man- "I can give you wishes...I can give you time to study, money to buy gold thread and rare glazes... Tell me about your work, and I can show you how to improve it and make lots of money" (p.77-78) - are highly suggestive of America as a Promised Land, a land of freedom and hope. And finally, when the young man decides to leave, he tells the lady that he has already done the most elegant work in his life and has given her his best pieces of art. This indicates that American dream, like the fancy love, can never last long. And Chinese immigrants, like the young man, being exploited, having contributed their youth to America, had to confront the disillusionment of their Gold Mountain dream.

In China Men, contrasted with the young man's adventure, Kingston provides a version of Baba's story in America. $\mathrm{BaBa}$ was lured to America by the stories of the Gold Mountain, which were retold and relished in his family:

"On the Gold Mountain, a man eats enough meat at one meal to feed a family for a month", said great grandfather. "Yes, slabs of meal." The hungrier the family got, the bigger the stories, the more real the meat and the 
gold..."American - a peaceful country, a free country.” America. The Gold Mountain. The Beautiful Nation. (p.42)

But quite different from the young man in "The Ghostmate" who is offered sumptuous meal, comfortable lodgings, love, promises of wealth, and above all, singular raw materials for his craft, BaBa and his fellow laundrymen's life in America was just a sort of Spartan existence. They gulped their food in "four-and-a half-minutes" before returning to work (p.60), made "the ironing tables into beds"(p.63), and lived for a long while without women. Unlike the young man who can fulfill his artistic and sexual desires, $\mathrm{BaBa}$ was frustrated on both counts. Instead of practicing calligraphy, he did bookkeeping for the laundry. When asking the blonde dancer to come home with him with his stammering English, he was politely yet firmly rejected. "No, honey." "No" (p.66). Thus from both mythical level and historical level, Kingston deconstructs the alluring Gold Mountain myth.

Kingston returns to the myth that China Men are the pioneers of the New World in "The Adventures of Lo Bun Sun," a myth adapted from Defoe's Robinson Crusoe (1719). In Kingston's version, "The Adventures of Lo Bun Sun" is depicted as a "book from Chinese about a sailor named Lo Bun Sun" (p.224). And Robinson, the typical colonizer and pioneer in western culture, is naturalized by Kingston to be a mythic Chinese American figure, which can be seen from the multiplicity of meaning in his name:

Lo Bun Sun worked. He was never idle, never lazy. He farmed the land. There is drudgery in his name: Lo is "toil", what one does even when unsupervised; he works faithfully, not cheating. Lo means "naked", man "the naked animal," and Lo also sounds like the word for "mule," a toiling animal, a toiling sexless animal. Bun is the uncle who went to China to work on a commune. And sun in like "body" and also "son" in English and "grandson" in Chinese. Sun as in "new." Lo Bun Sun was a mule and toiling man, naked and toiling body, alone, son and grandson, himself all the generations. (p.226)

The identity demystification makes it clear that Lo Bun Sun is a typical Chinese American who, being called coolie, is destined to toil and sweat all his life. Living in a bachelor society as a result of the laws depriving him of opportunity to approach women, he is relegated as a sexless mule.

Then Kingston tells the adventures of Lo Bun Sun in the Chinese American context. Just like Kingston's pioneering (fore)fathers who as "ocean people" knew the immensity of the world and could hear " the sirens Odysseus heard," Lo Bun Sun has "a calling to go to sea" (p.87, 225). After the shipwreck, Lo Bun Sun rescues rice, barley, wheat, flour, clothes, ink, pens, paper, guns pistols, hatches, ax, saw, tobacco and the like from the ship. Abundant as the store is, Lo Bun Sun does not loaf and tan himself on the beach, nor does he rap or play. Instead, he begins farming the land. In his spare time, he writes diary, makes tofu, bean sauce, bread, shapes pots, tames parrots and creates new Four Valuable Things when the old ones are used up. Later, he rescues a captive from a group of savages, names him Sing Kay $\mathrm{Ng}$, Friday in Cantonese accent, and teaches him to read and write. Finally, with nearly thirty years of toiling, he cultivates the land, grows crops, builds his house, and raises a herd of birds. "He was king of his own island" (p.229).

The adventure of Lo Bun Sun in an alien island mirrors early Chinese Americans' cultivating the American wilderness and building the American West. After years of backbreaking labor, Bak Goong and other Chinese workers not only hacked a farm out of the wilderness, but also became "the first human beings to dig into the part of the island and see the meat and bones of the real earth" (p.100). Bak Goong is explicitly compared to be the prince of the land in Kingston's description: "One day, like a Knight rescuing a princess, Bak Goong broke through the thicket" (p.100). Ah Goong, on the other hand, possessed the land and made himself the father of the American west by felling trees, cutting tunnels, and "fucking the world". Just as Lo Bun Sun replaces Robinson and becomes the master of the land, in the case of Bak Goong and Ah Goong, the servant-empress relationship between America and China Men is reversed. Instead of being compelled to serve the domineering empress, these Tang Aos were cast as American western pioneers.

Thus by refashioning the myth of western archetype of colonizer into a Chinese Lo Bun Sun myth, Kingston mythologizes the history of Chinese American, and makes it a part of the American pioneering mythology.

The myth of America as a cultural melting pot is challenged in "The Li Sao: An Elegy", for this myth constitutes a sharp contrast to the cultural myth of America as a melting pot for the immigrants. America likes to boast herself as symbols of racial tolerance and melting pot. The concepts they advocate - the Statue of Liberty, liberty and justice for all — all beckon to immigrants from other parts of the world. But unlike Caucasian immigrants, Chinese were permanent aliens in America. This proves that while faith in the American dream and possibilities of realizing it are widespread, it is not universal. To those of the "superior race", America appears to be the Promised Land and a Utopian paradise, but immigrants of the "inferior race" must have felt disillusionment and despair as their notions of melting pot and the land of freedom clash with reality. Thus by presenting the misery of Chinese diaspora, Kingston challenges the authenticity of the myth of America as a cultural melting pot.

In a word, myth-rewriting is of great significance to the history-writing in China Men. By adapting and transforming myths of various origins, Kingston deconstructs the popular American myths, such as the Gold Mountain myth, Western Frontier myth, and myth of America as a melting pot, and meanwhile reconstructs myth of China Men as the pioneers of the country and builders of the Gold Mountain. Moreover, by exploring the predicament of Chinese Americans at the mythic level, Kingston aggrandizes the themes and characters of the historical narrative.

Thus through these radical means, Kingston reconstructs her version of Chinese American history. However, it is worth mentioning that Kingston's narrative does not partake of a struggle for truth, but interrogates the status of truth, or what defines and creates truth. Her purpose of creating an alternate history which exists and contradicts the dominant 
American history is to attest to the latter's failure as an all-powerful monologue.

"The Wild Man of the Green Swamp" is an example in point. In this episode, Kingston gives her alternate interpretation of an official report on a wild Chinese man. The newspaper describes a Chinese man living in the swamp as an unkempt and uncivilized wild man. But from the photography in the newspaper Kingston sees a vulnerable man who did not look insane. Kingston's interpretation presents another truth for the wild man, which renders the official appraisal dubious. What she does here is not to assert that she is absolutely right, but by creating multiple versions, she hints that no one truth is absolute or all encompassing. Therefore, in this way Kingston challenges the traditional notion of American history and official document as an absolute authority, and demands that history should be rethought, refocused, and represented.

Kingston thus concludes the book appropriately with the section "On Listening”, in which the narrator, as a good listener and story-teller, emphasizes the importance of heterogeneity as well as listening. At a party she is told diverse stories about her Chinese ancestor's quest for the Gold Mountain, set variously in the Philippines, Mexico, and Spain. Kingston let these heterogeneous versions coexist and form a dialogue between each other, because, in her opinion, heterogeneity does necessarily constitute a subversion of authority. After presenting multiple versions of stories, Kingston closes the book with the sentence: "Good. Now I could watch the young men who listen" (p.308). In this sentence, Kingston puts her faith in the young men who listen to her stories, and sees if they have benefited from fabulation as she herself gives up trying to establish the facts of any particular version. Kingston's implication is that the young men should know the importance of listening, and only by learning to listen to different dialogical voices can they have their own history and identity.

In many interviews, Kingston stresses that she is writing not just to her family, to her Chinese American community, but to the broader culture, to "Americans in general", to people living today and in the future. This is well illuminated in China Men. Really, Kingston in this book not only just "re-reads the past", but by the very act of telling, attempts to "reshape the future." She hopes that the young generations of ethnic minority in America, empowered by the ability to articulate their past, can learn to establish their identity and culture, and the young generations of Anglo-America, acquiring the knowledge of other ethnic minorities by listening, can learn to respect other ethnic minorities and their histories. As Huntley notes, “China Men thus concludes with a vision of a new America” (Huntley, 1998, p.153).

\section{CONCLUSION}

In addition to recounting her family saga as a counter-memory, Kingston also employs re-reading facts, and rewriting myths as strategies to reconstruct history. The archival works such as discriminatory law, photography, newspaper reports form an essential part of counter-memory and challenge the authority and authenticity of mainstream American history. Whereas the myths not only help Kingston find a way to write her ancestors into American history, but also augment and elevate the existing history to the mythic level. Moreover, by depicting those brave Chinese souls as American pioneers, Kingston writes Chinese Americans into the American Frontier mythology, and deconstructs a series of American myth such as the Gold Mountain myth, the myth of America as a melting pot. Therefore, in her efforts to write Chinese Americans back into the history of America, Kingston subverts the notion of a seemingly seamless factual history, untouched by either mythology or particularity, and exposes the mythological roots of Anglo-America history by putting its claim to objectivity and truth into jeopardy.

Thus by interweaving personal and national events, fantasy and facts, talk-story and myth, Kingston presents another version of Chinese American history to expose the bigotry of history monopolized by the dominant American culture. Kingston's version does not intend to finalize the truth of history, but to exhibit the various aspects of history, so that it can demystify the authority of monologic history, and carve a place for Chinese Americans in American history.

Kingston's courage to reclaim the silenced history in this radical way inspires other Chinese American writers to join in this struggle. In 1991, Frank Chin's Donald Duk and Shawn Wong's Homebase were published. These works unearth the buried history, modify the still-functioning stereotypes about the Chinese, form an indispensable part of Chinese Americans' struggle for power, and promote a Chinese American culture. Kingston's contribution also lies in her encouraging other minority writers to write their past and fight for equality. And their joint efforts constitute the whole scene of righting the world and empowering the minority group. Therefore, with more writers joining this struggle, we are justified to believe that the future of Chinese Americans will become better.

\section{REFERENCES}

[1] Bonetti, Kay. (1998). “An Interview with Maxine Hong Kingston”. Skenazy, Paul \& Martin, Tera. (ed.) Conversations with Maxine Hong Kingston. Jackson: University Press of Mississippi.

[2] Cheung, King-Kok. (1993). Articulate Silences: Hisaye Yamamoto, Maxine Hong Kingston, Joy Kogawa. Ithaca: Cornell University Press.

[3] Foucault, Michel. (1980). Power/Knowledge: Selected Interviews and Other Things 1972-1977. Ed. Colin Gordon. Trans. Colin Gordon, et al. New York: Pantheon Books.

[4] Gao, Yan. (1996). The Art of Parody: Maxine Hong Kingston's Use of Chinese Sources. New York: Peter Lang.

[5] Goellnicht, Donald C. (1992). "Tang Ao in America: Male Subject Positions in China Men". Reading the literatures of Asian American. Eds., Shirley Geok-lin Lim and Amy Ling. Philadelphia: Temple University Press, 191-211. 
[6] Huntley, E. D. (1998). Maxine Hong Kingston: A Critical Companion. Westport: Greenwood Press.

[7] Kim, Elaine H. (1982). Asian American Literature: An Introduction to the Writings and Their Social Context. Philadelphia: Temple University Press.

[8] Kingston, Maxine Hong. (1980). China Men. New York: Vintage International.

[9] Lee, Robert G. (1992). "The Woman Warrior as an Inversion in Asian American Historiography". Approaches to Teaching Kingston's The Woman Warrior. Ed. Shirley Geok-lin Lim. New York: MLA, 52-63.

[10] Yuan,Yuan. (1999). "The semiotics of China Narrative in the Contexts of Kingston and Tan", Critique: Studies in Contemporary Fiction, Spring 99, Vol.40 Issues 3, 292-303.

[11] Zackodnik, Teresa C. (1997). "Photography and the Status of Truth in Maxine Hong Kingston's China Men", MELUS; Fall 97, Vol.22 Issue3, 55-67.

Minglan Zhang was born in Shandong, China in 1967. She received her M.A. in English Literature from Guangxi Normal University, China in 2005. She is currently a lecturer in Foreign Language College, Huaiyin Institute of Technology, Jiangsu, China. Her research interests include English and American literature.

Fade Wang was born in Shandong, China in1967. He received his M.A. in English language and literature from Shandong University, China in 1995. He is currently an associate professor in Foreign Language College, Huaiyin Institute of Technology, Jiangsu, China. His research interests include bilingual translation between English and Chinese, inter-cultural communication, and contrastive study between Eastern and Western cultures. 